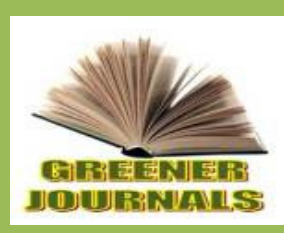

\title{
Screening of Endophytic Bacteria Associated with Ceratonia siliqua L. Plant Using Molecular Marker Repetitive Extragenic Palindromic (Rep)-PCR
}

\author{
Ibrahim Konate ${ }^{1 *}$, Mathurin Koffi ${ }^{1}$, Annick Koulibaly', \\ Amina Sorouri², El Bekkay Berraho², \\ Abdelkarim Filali-Maltouf ${ }^{2}$
}
${ }^{1}$ Unité de Formation et de Recherche en Agroforesterie et en Environnement, Laboratoire des Interactions Hôte-Microorganisme, Environnement et Evolution (LIHME), Université Jean
Lorougnon Guédé, B.P: 150 Daloa, Côte d'lvoire.
${ }^{2}$ Faculty of Sciences, Laboratory of Microbiology and Molecular Biology, University
Mohammed V-Agdal, Rabat, Morocco.

Article No.: 121114393

DOI: 10.15580/GJAS.2015.1.121114393

Submitted: 12/11/2014

Accepted: 21/01/2015

Published: 05/02/2015

*Corresponding Author

Ibrahim Konate

E-mail: konatibrahim@yahoo.fr

Phone: (+225) 32787570

Keywords:

Enophytic bacteria, Carob

(Ceratonia siliqua L), REP-PCR,

screen, genetic diversity
Repetitive extragenic palindromic (Rep)-PCR was used to screen and to characterize the natives endophytic bacteria isolated from roots (IRC) and epicotyls (IEC) of young carob (Ceratonia siliqua L.) plant collected from different Moroccan localities. Genomic DNA of 80 bacteria (69 IRC and 11 IEC), 7 strains of $\mathrm{RCM}$ and 13 strains of reference rhizobia were successfully carried. The complementary primers of Rep induced reproducible PCR fingerprint patterns and generated more bands polymorphs and useful for distinguishing the isolates from each other. We obtained respectively 6, 17 and 35 polymorphic bands with IEC, RCM and IRC strains with the size ranging between 380 to $7250 \mathrm{pb}$. Dendrogram based upon UPGMA analysis of Rep-PCR patterns showed high degree of genetic diversity among indigenous carob endophytic bacteria. At $87 \%$ of similarity, we revealed a wide polymorphism and obtained 2 greats clusters, 6 smalls groups and 24 independent lines. Rep-PCR technology allowed us, firstly to characterize 14 IRC genetically belonging to RMC, Sinorhizobium sp, Rhizobium sp and Agrobacterium sp; and secondly, to revalue the exact number of our collection to 45 strains and to select excessively34 endophytic bacteria original from seven Moroccan regions for futures works. 


\section{INTRODUCTION}

The carob (Ceratonia siliqua L.) tree is a leguminous of the Ceasalpinoideae subfamily that grows in most countries of the Mediterranean basin, usually in mild and dry places with poor soils (Batlle and Tous, 1997). In Morocco, it is present as spontaneous or artificial populations on the large part of the countries and up to $1150 \mathrm{~m}$ in altitude (Emberger and Maire, 1941). Actually, an efficient agroforestry program is conduct, in Morocco, to recover the deforestations areas using multipurpose plants species that are able to grow in inappropriate soils such as carob (Konate et al. 2007).

Ceratonia siliqua L. plant is an important of vegetation for environment, economic and social reason. It is known to survive adverse environmental condition including dryness, salinity (up to $3 \% \mathrm{NaCl}$ ) and adapt to a wide range of soil type from poor sandy and rocky (Winer 1980; Batlle and Tous, 1997). Carob tree play an important role in the conservation and improvement of soil fertility.

Long lime ego, carob tree, like most legumes belong to Ceasalpinoideae subfamily, was considered to be not nodulate and unable to fix atmospheric nitrogen (Martins-Louçâo and Rodriguez-Barrueco, 1982; Martins-Loucâo, 1985). In 1996, Misbah et al. reported isolation and characterization on phenotypical features of the symbiotic bacteria associated with carob tree. Soon after, the activity of the enzyme nitrogenase was detected, in vitro culture, inside the carob roots and bourgeons (Byan et al. 1996). Therefore, the application of bioinoculant, platntgrowth promoting rhizobacteria (PGMR) such as endophytic bacteria Azospirillum, improved the performance of carob plants by nitrogen fixation by a mechanism other than nodulation (El-Refarey et al. 2011).

Endophytic bacteria are defined as those bacteria that colonize the internal tissue of the plant showing no external sign of infection or negative effect on their host (De Bary, 1986; Schulz and Boyle, 2006; Prabhat et al. 2013). According to space colonized by endophytic bacteria, we distinct symbiotic bacteria which reside in the internal cell and form structural nodule efficient and associative bacteria that colonize the intercellular spaces without forming structural nodule (Stone, 1986; Baldani and Baldani, 2005). Nearly, 300000 plants species (monocotyledonous and dicotyledonous) in the world, each of them is host to one or more endophytes (Strobel et al., 2004). However, a few of these plants have ever been completely studied to their endophytic biology (Ryan et al. 2008).

The beneficial action of these endophytic bacteria consist in producing and delivering growthpromoting substances to plants, stimulating the expression of growth-gens in plant, facilitating the uptake of minerals from the soils, limiting the negative influence of toxic heavy metals, exerting an antagonistic action against pathogens and increasing plant resistance to abiotic stresses (Joseph et al. 2007; Lisk et al. 2011; Sturz and Mathson, 1996; Yanni et al. 2007; Ryan et al. 2008; Yousr et al. 2014).
Distinguishing bacterial isolates on the base of physiological, biochemical and biological tests is not always sufficient to differentiate very well between the different populations. DNA markers are stable and unaffected by the environment and the bacterial physiology and present a very effective tool for identification and rapid analysis of the genetic diversity among bacterial populations. So, the molecular biology techniques based on the PCR reaction, such as repPCR, have begun always used to screen the new bacterial collections.

Moreover, Repetitive Element Polymorphism (Rep)-PCR fingerprinting, developed by Versalovic et al. (1991), has become a frequent method to distinguish bacteria species analyzing the distribution of repetitive DNA sequences in several prokaryotic genome. The Rep-PCR technique is reliable, reproducible, simple and rapid to make, in addition reveal a high efficiency with the discrimination of microorganisms, even among population of the same species (Versalovic et al. 1994; Rademaker and De Bruijin, 1997; da Silva and Valicente, 2013). Genomic DNA fingerprints generated with short arbitrary primers and repetitive extragenic palindromic have provided the highest level of taxonomic resolution currently attainable by PCR methods (De Bruijn, 1992; Agius et al. 1997; Niemann et al. 1997; Tajima et al. 2000).

The technique Rep-PCR has been successfully applied to the characterization and the identification of field isolates of S. Meliloti (De Bruijn, 1992; Niemann et al. 1997), B. Japonicum (Judd et al. 1993), R. Galeae (Nick and Lindstrom, 1994), Frankia (Murry et al. 1995), Xanthomonas sp. (Louws et al. 1995), R. Leguminosarum (Tajima et al. 2000), Pseudomonas sp. (Lisek et al. 2011) and Bacillus thuringinesis (Reyes-Ramirez and Ibarra, 2005; da Silva and Valicente, 2013). However, any data have been reported on the application of this technique to symbiotic or associative bacteria isolated from carob (Ceratonia siliqua L.) tree. Only, the results obtained in 1996 by Misbah et al. and Byan et al., respectively on the phenotypic characterization of rhizobia nodulated carob seedling and on the nitrogenase activity observed, in vitro culture, inside the carob vegetative organs, are available. Here, we aim to use the repPCR technique to (i) characterize and screen the native strains of endophytic bacteria isolated from roots (IRC) and epicotyls (IEC) organs of carob seedling collected from eleven Moroccan localities and (ii) to analyze the molecular diversity among carob symbiotic bacteria (RCM) previously described by Misbah et al (1996).

\section{MATERIALS AND METHODS}

\section{Plant material}

The seeds used in this work were obtained from pods collected from 11 regions of Morocco: Taourirt, Al Houceima, Taounate, Aïn Safa, Akchort, Demnate, Ouazzane, Sidi Bou Othmane, Essaouira, Tetouan and Ouad Lou. Each collection of seeds was referred 
to its region of origin as a separate accession. Soil sample were also collected in each region.

Scarification, sterilization and germination of seeds were carried out as described by Konate et al. (2009). After the germination of seeds on sterile water agar $(0.7 \% \mathrm{w} / \mathrm{v})$, plates were incubated at $28^{\circ} \mathrm{C}$ in obscurity. The young seedlings were transferred in pots containing soil of the same origin then placed in a growth chamber.

\section{Isolation of endophytic bacteria}

After six months of cultivation roots and epicotyls of young carob seedlings were used for bacterial isolation.

\section{Isolation from roots}

The roots of carob tree were not uniform. We have found filament and finger forms. Finger forms of roots, was washed several times with sterile water, sterilized with $0.1 \% \mathrm{HgCl}_{2}$ for $5 \mathrm{~min}$ under vigorous shaking, and washed thoroughly with sterile water and then ground with $1 \mathrm{~mL}$ of pure water. The mixed tissue $(0.5 \mathrm{~mL})$ was spotted on YEM medium (Vincent, 1970) and incubated at $28^{\circ} \mathrm{C}$.

\section{Isolation from epicotyls}

Epicotyls were successively treated with SDS $(0.01 \%)$ for $2 \mathrm{~h}$, with $\mathrm{HgCl}_{2}(0.2 \%)$ for 10 min then washed with sterile water. Epicotyls portions of $0.5 \mathrm{~cm}$ to $1 \mathrm{~cm}$ were sectioned, transferred on sterile water agar plates $(0.7$ $\% \mathrm{w} / \mathrm{v}$ ) then incubated at $28^{\circ} \mathrm{C}$.

\section{Rhizobial strains}

Thirteen reference strains belonging to Rhizobium (STM), Mesorhizobium (ORS), Sinorhizobium (ORS), Bradyrhizobium (USDA) and Agrobacterium (ORS) were used.

Seven strains nodulating carob (RCM) roots, previously described by Misbah et al (1996), were also included in this study.

\section{Isolation of DNA}

Genomic DNA was isolated using Phenol Extraction Protocol described by Ausubel et al. (1987). Purified DNA was dissolved in $50 \mu \mathrm{L}$ TE buffer (pH7.8). The concentration of DNA was assessed spectrophotometrically, readied at absorbance of 260 $\mathrm{nm}$ and calculated using following formula. Concentration of DNA $(\mathrm{ng} / \mu \mathrm{l})=\mathrm{OD}_{(260 \mathrm{~nm})} \times 50 \times$ dilution factor.

\section{Rep-PCR}

The PCR mix and reactions were carried out as described by de Bruijn (1992) using the sequences of primers complementary designed by Versalovic et al (1991) : REP RI (5'-IIIICGICGICATIGGC-3') and REP RII (5'-ICGICTTATCIGGCCTAC-3'). Template DNA at
$100 \mathrm{ng}$ of each stain was used for the amplification. PCR reactions were carried out in a $28 \mu \mathrm{l}$ volume containing $3 \mu \mathrm{l}$ of PCR buffer $(10 \mathrm{x}), 0.3 \mu \mathrm{l}$ of each primers (30 pmol) Rep I and Rep II, $1.2 \mu \mathrm{l}$ of each nucleotide $(10 \mathrm{mM}), 3.5 \mu \mathrm{l}$ of $\mathrm{MgCl}_{2}(25 \mathrm{mM}), 3 \mu \mathrm{l}$ of DMSO $(10 \%), 1 \mu \mathrm{l}$ of BSA $(20 \mathrm{mg} / \mathrm{ml}), 0.5 \mu \mathrm{l}$ of Taq DNA polymerase $(5 \mathrm{U})$ and $1 \mu \mathrm{l}$ of each DNA. The amplification was performed in thermo-cycler AMPLTRON-RII according to the thermal cycling program by Grundman et al. (1997). The products of the PCR reactions $(15 \mu \mathrm{ll})$ were separated by electrophoresis in $1.2 \%$ agarose gel prepared with TBE buffer. The migration was performed at 80 volts for $4 \mathrm{~h}$ and the visualisation of Rep profiles has been done with ethidium bromide $(10 \mathrm{mg} / \mathrm{mL})$ under ultraviolet light.

The amplification products were scored as presence (1) and absence (0) of band for each of strain analyzed and transformed into binary matrixes. Cluster analysis was performed with the fingerprinting patterns using the Dice similarity coefficient and the unweightedpair- method, with arithmetic means (UPGMA).

\section{RESULTS}

\section{Root and epicotyl endophytic bacteria}

In the present study, we showed that endophytic bacteria were successfully isolated from vegetative organs of carob (Ceratonia siliqua L) seedlings collected from different geographical and ecological areas of Morocco. Except two accessions, Taourirt and Al-Houceima, the presence of bacteria in the roots and the epicotyls organs was found with the plant of others accessions. Strains isolated from roots were coded as IRC (Isolates Root Carob) and same strains isolated from epicotyls were coded IEC (Isolates Epicotyls Carob).

A total, 73 endophytic bacteria were isolated from roots (IRC) and were obtained with 9 accessions. The high numbers of these endophytes were obtained from Taounate accession with $26 \%$ of isolates and from Ouazane accession with $20.5 \%$ of isolates. For the others accessions, percentage of isolates obtained were respectively $16.4,12.4,9.6,5.5,4.1$ and 1.4 with Tetouan, Oued Laou, Demnate, Aîn Safa, Sidi Bou Othmane, Essaouira and Ouazane. 69 of the strains were used for Rep-PCR analysis.

11 endophytic bacteria were isolated from epicotyls and were obtained with plants originating from three accessions. $54.5 \%$ of isolates were obtained from Sidi Bou Othaman accession, $36.4 \%$ and $9.1 \%$ of isolates were native to Taounate and Essaouira accessions.

\section{Rep-PCR}

The DNA patterns generated by complementary REP primers were visible and reproducible. The number of bands was variable according to strain origin. For IRC, we obtained 1 to 11 fragments per strain with a total of 
35 distinct and polymorphic bands with the size ranging between 380 to 7250 pb (Fig. 1A). For IEC, 2 to 4 fragments were generated per strain with a total of 6 polymorphic bands with the size ranging between 1740 to 6025 pb (Fig. 1B). For RCM, the number of bands varied from 2 to 11 with a total of 17 different fragments with the size ranging between 660 to 4170 pb (Fig. 1A).

The dendrogram constructed on pair-wise comparison of Rep fingerprints showed the high degree of genetic diversity among the IRC, IEC and RCM strains analysed (Fig. 2). In fact, we revealed a wide polymorphism at $87 \%$ of similarity and obtained 8 clusters, composed in 2 great's clusters and 6 smalls groups, and 24 independent lineages. The first great cluster contained only 18 ICR, all IEC and RCM5 strains and the second was composed by Sinorhizobium sp and 3 IRC strains. However, the 6 smalls groups contained 11 IRC, RCM3 and RCM4 strains that belong to different species of Rhizobium $\mathrm{sp}$ and Agrobacterium sp.

The results allowed us to screen and revalue clearly the exact number of the strains in our collection. We obtained 41 strains for roots bacteria (IRC) and only 3 strains for epicotyls bacteria. So, 30 IRC and 4 IEC different strains representing the various Rep-PCR groups and free lines were exceptionally selected for the further analysis (Table 1).

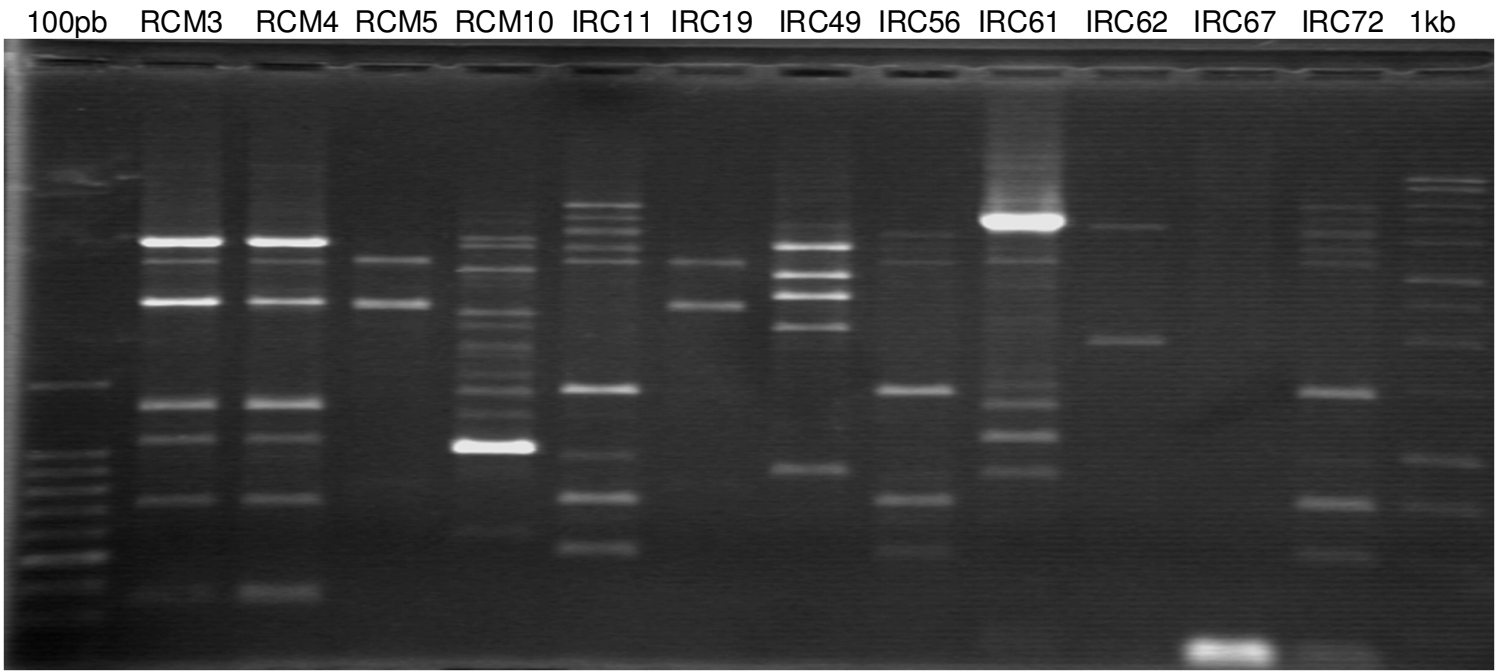

A

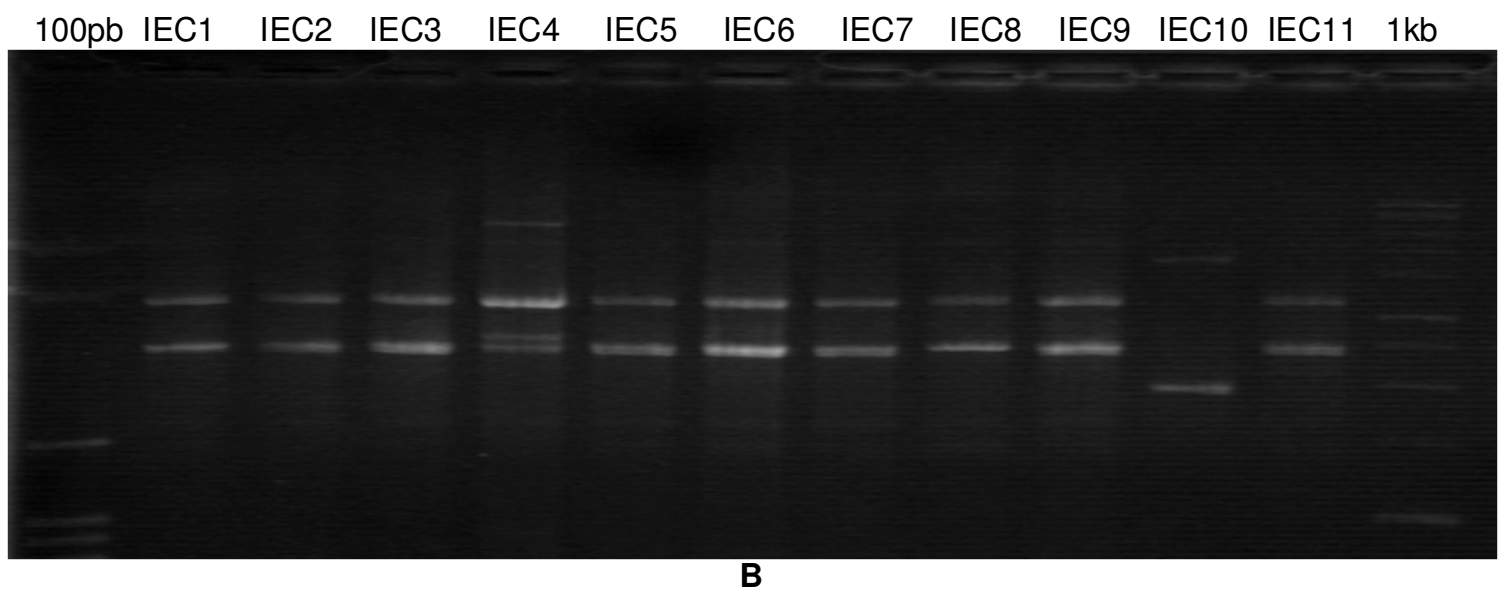

Figure 1. Rep-PCR profile generated with the REP RI and REP RII primers. (A): DAN patterns of endophytic bacteria isolated from roots (IRC) of carob seedling and symbiotic carob bacteria (RCM) described by Misbah et al. (1996). (B): DAN patterns of endophytic bacteria isolated from epicotyls (IEC) of carob seedling. 


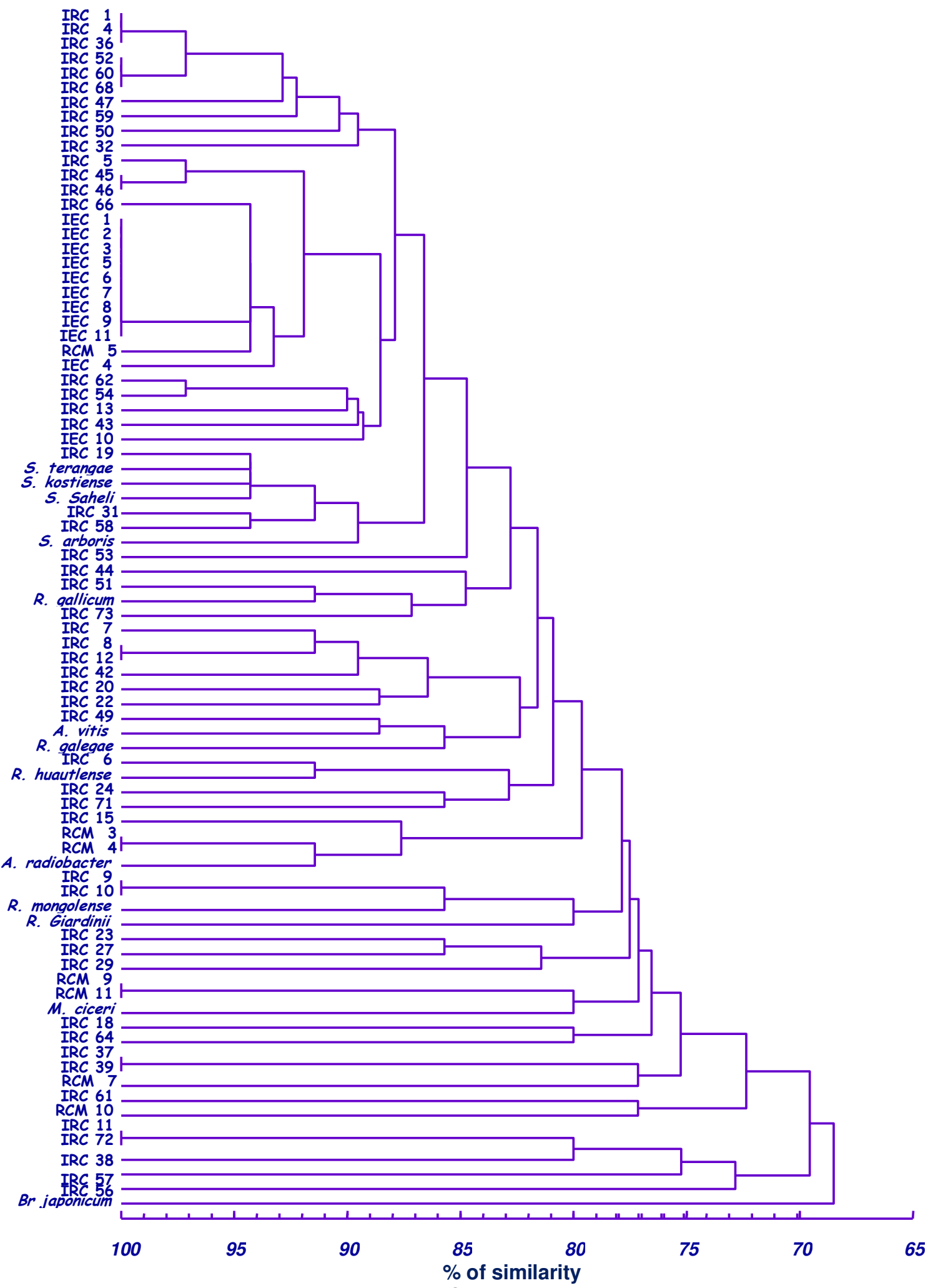

Figure 2. Dendrogram generated from Rep-PCR fingerprints data of endophytic bacteria isolated from roots (IRC) and epicotyls (IEC) of carob plants seedling, symbiotic bacteria (RCM) of carob (Misbah et al. 1996) and thirteen reference strains using UPGMA clustering method 
Table 1: Strains of roots (IRC), epicotyls (IEC) and carob symbiotic (RCM) selected by Rep-PCR data

\begin{tabular}{|c|c|c|c|c|}
\hline $\mathbf{N}^{\circ}$ & $\begin{array}{l}\text { Isolate } \\
\text { coded }\end{array}$ & Origin of host plant & $\begin{array}{l}\text { Number of the } \\
\text { bands }\end{array}$ & $\begin{array}{l}\text { Molecular weight (range, } \\
\text { pb) }\end{array}$ \\
\hline 1 & IRC1 & Oued Laou & 2 & $832-3981$ \\
\hline 2 & IRC6 & Ouazzane & 5 & $725-3981$ \\
\hline 3 & IRC7 & Tétouan & 7 & $725-3311$ \\
\hline 4 & IRC9 & Taounate & 7 & $725-4570$ \\
\hline 5 & IRC11 & Taounate & 9 & $525-6025$ \\
\hline 6 & IRC15 & Tétouan & 6 & $1047-4169$ \\
\hline 7 & IRC18 & Ouazzane & 6 & $2042-4169$ \\
\hline 8 & IRC19 & Ouazzane & 2 & $2511-3801$ \\
\hline 9 & IRC20 & Tétouan & 4 & $955-2884$ \\
\hline 10 & IRC24 & Taounate & 3 & $725-2884$ \\
\hline 11 & IRC27 & Taounate & 6 & $955-4570$ \\
\hline 12 & IRC29 & Ouazzane & 6 & $725-4570$ \\
\hline 13 & IRC32 & Ouazzane & 4 & $832-5248$ \\
\hline 14 & IRC37 & Taounate & 7 & $380-3162$ \\
\hline 15 & IRC42 & Sidi Bou Othman & 4 & $725-1548$ \\
\hline 16 & IRC43 & Tétouan & 2 & $1445-2042$ \\
\hline 17 & IRC44 & Essaouira & 4 & $1047-2511$ \\
\hline 18 & IRC45 & Essaouira & 3 & $725-3162$ \\
\hline 19 & IRC47 & Tétouan & 3 & $3162-7244$ \\
\hline 20 & IRC49 & Aïn Safa & 6 & $955-5012$ \\
\hline 21 & IRC50 & Aïn Safa & 4 & $832-7244$ \\
\hline 22 & IRC51 & Aïn Safa & 6 & $380-1995$ \\
\hline 23 & IRC53 & Taounate & 4 & $525-2239$ \\
\hline 24 & IRC54 & Demnate & 1 & 5012 \\
\hline 25 & IRC56 & Taounate & 11 & $382-6026$ \\
\hline 26 & IRC57 & Taounate & 7 & $525-6607$ \\
\hline 27 & IRC58 & Aïn Safa & 3 & $1995-4898$ \\
\hline 28 & IRC61 & Demnate & 7 & $955-5012$ \\
\hline 29 & IRC66 & Ouazzane & 2 & $832-3162$ \\
\hline 30 & IRC73 & Sidi Bou Othman & 3 & $832-1995$ \\
\hline 31 & IEC1 & Sidi Bou Othman & 2 & $2239-3162$ \\
\hline 32 & IEC4 & Sidi Bou Othman & 4 & $2239-6025$ \\
\hline 33 & IEC10 & Essaouira & 2 & $1737-4570$ \\
\hline 34 & IEC11 & Sidi Bou Othman & 2 & $2239-3162$ \\
\hline
\end{tabular}

\section{DISCUSSION}

These results showed that carob tree is the natural host of associative rhizobacteria and confirmed the result obtained by Bryan et al (1996) who detected the enzyme nitrogen activities within carob roots and bourgeons in vitro culture. The absence of associative bacteria in plant internal tissue of Taourirt and AlHouceima accessions demonstrated existent of compatibility and selectivity between the both associates. The plant, naturally select endophytes which can fit competitively to occupy compatible niches within its nutritionally-enriched and protected habitat of its internal tissues without causing pathological symptoms on the host plant (Kleopper and Beauchamp 1992). Many plants as Oriza sativa (Yanni et al. 1997; Eteami et al. 2014; Van and Cao Ngoc, 2014), Gossypium sp. (Misaghi and Donndelinger, 1990; Reva et al. 2002), Vitis vinifera (Compant et al. 2005), Picea abies (Shichido et al. 1999), Coffea arabica (Jimenez-Salgado et al. 1997), Zea mays (Chabot et al. 1996; Singh et al. 2013),
Helianthus petiolaris (Alami et al. 2000), Triticum aestivum (Webster et al. 1997; Afzal and Bano, 2008), Capsicum annum (Amaresan et al. 2014 ), Musa spp. and Ananas comosus L. (Cruz et al. 2001) were reported to establish beneficial association with different type of endophytic bacteria.

The complementary primers of Rep induced reproducible PCR fingerprint patterns and generated more bands polymorphs and useful for distinguishing the isolates from each other. We obtained respectively 6, 17 and 35 polymorphic bands with IEC, RCM and IRC strains with the size ranging between 380 to 7250 $\mathrm{pb}$. Several study showed that the number of the distinct fingerprinting patterns generated by Rep-PCR varied widely from 1 to 4 (da Silva and Valicente, 2013), to 9 (Ogutcu et al. 2009; Lisek et al. 2011) and to 11 (Spigalla and Mastratonio, 2003) fragments in size of 250 to $3054 \mathrm{pb}$ (da Silva and Valicente, 2013), to 4700 (Ogutcu et al. 2009; Lisek et al. 2011) and to 5000 pb (De Bruijn, 1992; Spigalla and Mastratonio, 2003). 
The dendrogram data revealed that all symbiotic bacteria (RCM) and associative bacteria (IRC and IEC) of carob plant showed a good relationship between them and a good number of these strains have been belong to the some species of Rhizobium. Naturally, Rhizobium ssp. are known to form nodules in legumes and prove through atmospheric $\mathrm{N}_{2}$ fixed by nitrogenase in rhizobial bacteroids to their host. However, several study showed that Rhizobiump possess the faculty that allow to them change their classic ecological niche and associate beneficially with a wide host of non-legumes plants as cereal and woody plants (Alami et al. 2000); Gutiérrez-Zamora and Martibez-Romero, 2001). Divers range of rhizobial strains were recently reported as natural endophytes like $R$. leguminosarum bv. phaseoli, trifolii and viceae (Chabot et al. 1996; Yanni et al. 1997; Chi et al. 2000, Matiru and Dakora, 2004), Rhizobium sp. (Alami et al. 2000; Gutiérrez-Zamora and Martibez-Romero, 2001; Afzal and Bano, 2008), Bradyrhizobium japonicum (Matiru and Dakora, 2004), photosynthetic bradyrhizobia (Chaintreuil et al. 2000), Sinorhizobium meliloti (Matiru and Dakora, 2004), Azorhizobium caulinodans (Gough et al. 1996; O'Callaghan et al. 1997; Chi et al. 2000) and Burkholderia brasilensis (Baldani et al. 1997b).

\section{CONCLUSION}

The result in the present study showed clearly that carob (Ceratonia siliqua L.) plant shield inside the vegetative organ roots or epicotyls the rhizobacteria as natural associates and demonstrated that all Rep-PCR fingerprints performed with complementary primers were discriminate and useful for screening and characterization of endophytic associative or symbiotic bacteria of carob. All symbiotic bacteria (RCM) showed a good relationship to associative strains (IRC and IEC) of carob tree and have together the same host plant and a good number of these strains have been belong to the some species of Rhizobium.

\section{ACKNOWLEGMENTS}

This work was supported by the Moroccan project PROTARS I-P2T2/24 and by the IRD project No 01-2MAR-28-1.

\section{REFERENCES}

Afzal A. and Bano A. (2008). Rhizobium and phosphate solubilizing bacteria improve the yield and phosphorus uptake in wheat (Triticum aestivum). Int. J. Agri. Biol., 10: 85-88.

Agius F., Sangiunetti C. and Monza I. 1997. Strain specific fingerprints of Rhizobium loti generated by PCR with arbitrary and repetitive sequences. FEMS Microbiol. Ecol., 24: 87-92.

Alami, Y., Achouak W., Marol C. and Heulin T. 2000. Rhizosphere soil aggregation and plant growth promotion of Sunflowers by an exopolysaccharideproducing Rhizobium sp. strain isolated from Sunflower roots. Appl. Environ. Microbiol. 66: 3393- 3398.

Amaresan N. Jayakumar V. and Thajuddin N. 2014. Isolation and characterization of endophytic bacteria associated with chilli (Capsicum annum) grown in coastal agricultural ecosystem. Indian $\mathrm{J}$. Biotechnol., 13: 247-255.

Ausubel, F. M., R. Brent, R. E. Kingston, D. D. Moore, J. G. Seidman, J. A. Smith, and Struhl K. 1987. Current protocols in molecular biology. Volume 1, Wiley Interscience. Chapitre 1.2.1.

Baldani V. L. D., Oliveira E., Balota E., Baldani J. I., Kirchhof G. and Döbereiner J. 1997b. Burkholderia brasilensis sp. nov. uma espécie de bacteria diazótrofica endofítica. An Acad Bras Cienc. 69: 116.

Baldani, J. I., and Baldani V. L. D.. 2005. History on the biological nitrogen fixation research in graminaceous plants: special emphasis on the Brazilian experience. An. Acad. Bras. Cienc. 77: 549- 579.

Batlle I. and Tous J. 1997. Carob tree. Ceratonia siliqua L. Promoting the conservation and use of underutilized and neglected crops. 17. Institute of Plant Genetic and Crops Plant Research. Gatersleben/International Plant Resources Institute. Rome. Italy.

Bryan J.A., Berlyn G.P. and Gordon J.C. 1996. Towards a new concept of the evolution of symbiotic nitrogen fixation in the Leguminosae. Plant Soil, 186, 151-159.

Chabot, R., Antoun H., Kloepper J. W. and Beauchamp C. J. 1996. Root colonization of Maize and Lettuce by Bioluminescent Rhizobium leguminosarum biovar phaseoli. Appl. Environ. Microbiol. 62: 2767-2772.

Chaintreuil, C., Giraud E., Prin Y., Lorquin J., Bâ A., Gillis M., De Lajudie P. and Dreyfus B. 2000. Photosynthetic Bradyrhizobia are natural endophytes of the african wild rice Oryza breviligulata. Appl. Environ. Microbiol. 66: 54375447.

Chi F. S. H., Shen H. P., Cheng Y. X., Jing Y., Yanni G. and Dazzo F. B. 2005. Ascending migration of endophytic Rhizobia, from roots to leaves, inside rice plants and assessment to benefits to rice growth physiology. Appl. Environ. Microbiol. 71: 7271- 7278

Compant, S., Reiter B., Sessistsch A., Nowak J., Clément C. and Barka E. A. 2005. Endophytic colonization of Vitis vinifera L. by palnt growthpromoting bacterium Burkholderia sp. strain PsJN. Appl. Environ. Microbilo. 71: 1685- 1693.

Cruz L. M., Souza E. M., Weber O. B., Baldani J. I., Döbereiner J., and Pedrosa F. O. 2001. 16S rDNA characterization of nitrogen-fixing bacteria isolated from Banana (Musa sp.) and Pineapple (Ananas comosus (L.) Merril). Appl. Environ. Microbiol. 67: 2376- 2379. 
da Silva R.B. and Valicente F.H. 2013. Molecular characterization of Bacillus thuringiensis using repPCR. SpringerPlus, 2: 641.

De Bary A. 1866. Morphologie und physiologie der Pilze, Flechten und Myxomyceten. Hofmeister's Handbook of Physiological Botany, Vol. 2, Leipzig.

De Bruijn J. F. 1992. Use of repetive (Repetitive Extragenic Palindromic and Enterobacterial Repetitive Intergeneric Consensus) Sequences and the polymerase chain reaction to fingerprint the genomes of Rhizobium meliloti isolates and other soil bacteria. Appl. Environ. Microbiol, 21802187.

El-Refaey F. El-Dengawy A., Ahmed A. Hussein A. and Saad A.A. 2011. Improving growth and salinity tolerance of Carob seelings (Ceratonia siliqua L.) by Azospirillum inoculation. Am Euras. J. Agric. \& Environ. Sci. 11 (3): 371-384.

Emberger L. et Maire R. 1941. Catalogue des plantes du Maroc (Spermaphytes et Pteridophytes). Imprimerie Minerva. Alger.

Etesami H., Hosseini M. and Alikhani H.A. 2014. In planta selection of plant growth promoting endophytic bacteria for rice (Oryza sativa L.). J. Soil Sci. Pl. Nutr., 14(2): 491-503.

Gough C., Webster G., Vasse J., Galera C., Batchelor C., O'Callaghan K., Davey M., Kothari S., Dénarié J. and Cocking E. C. 1996. Specific flavonoids stimulate intercellular colonization of non-legumes by Azorhizobium caulinodans. Pages 409- 415 in: Biology of Plant-Microbe Interactions. G. Stacey, B. Mullin, and P. M. Gresshoff, eds, International Society for Molecular Plant-Microbe Interactions, St. Plant, MN, U.S.A.

Graham, P.H. and Parker C.A. 1994. Diagnostic features of the root-nodule bacteria of legumes. Plant Soil. 20: 383-396

Gutiérrez-Zamora M.L. and Martinez-Romero E. 2001. Natural endophytic association between Rhizobium etli and maize (Zea mays L.). J. Biotechnol. 91: 117-126.

Jimenez-Salgado T., Fuentes-Ramirez L. E., TapiaHernandez A., Mascarua-Esperanza A. M., Martinez-Romero E. and Caballero-Mellado J. 1997. Coffea arabica L. a new host for Acetobacter diazotrophicus and isolation of other nitrogen-fixing Acetobacteria. Appl. Environ. Microbiol. 63: 3676-3683.

Josph B., Ranjan P.R. and Lawrence R. 2007. Characterization of plant growth promoting rhizobacteria associated with chickpea (Cicer arietinum L.) Inter. J. Plant Produc. 2: 141-152.

Judd A.K., Schneider M., Sadowsky M.I. and Bruin F.I. 1993. Use of repetitive sequences and the polymerase chain reaction technique to classify genetically related Bradyrhizobium japonicum serocluster 123 strains. Appl. Environ. Microbiol. 59: $1702-1708$.

Kleopper, J. W., and C. J. Beauchamp. 1992. A review of issues related to measuring colonization of plant roots by bacteria. Can. J. Microbiol. 38: 12191232.

Konate I. Filali-Maltouf A. and Berraho E. B. 2007. Diversity analysis of Moroccan carob (Ceratonia siliqua L.) accessions using phenotypic traits and RAPD markers. Acta Botanica Malacitana, 32: 7990.

Konate I., Berraho E.B. and Filali-Maltouf A. 2009. Inter-Simple Sequence Repeat Markers Variation among Natural Accessions of Moroccan Carob Tree (Ceratonia siliqua L.), Inter. J. of Agri.Biol., 11: 168-172.

Lisek A., Paszt L.S., Oskiera M., Trzcinski P., Bogumil A., Kulisiewicz A. and Malusai E. 2011. Use of the rep-PCR technique for differentiating isolates of rhizobacteria. J. Fruit Ornam. Plant Res. 6: 5-12.

Louws F.J., Fulbrught D.W., Stephens C.T. and De Bruijn F.J. 1995. Differentiation of genomic structure by rep-PCR fingerprinting to rapidly classify Xanthomonas campestris pv vesicatoria. Phytopathol. 85: 528-536.

Martins-Loução M. A. 1985. Estudos fiisiogicos e microbiolócos da associaçâo da alfarrobeira (Ceratonia siliqua L.) com bactérias de Rhizobiaceae. PhD Thesis, Univ. of Lisbon, Portugal.

Martins-Loução M. A. and Rodríguez-Barrueco C. 1982. Studies in nitrogenase activity of carob (Ceratonia siliqua L.) callus cultures associated with Rhizobium. Pp. 671-672 in Proceedings V International Congress Plant Tissue Culture, Tokyo.

Matiru V. N. and Dakora F. D. 2004. Potential use of rhizobial as promoters of plant growth for inceased yield in landraces of African cereal crops. Afr. J. Biotechnol. 3: 1 - 7.

Misaghi, I. J., and C. R. Donndelinger, 1990. Endophytic bacteria in symptom-free cotton plant. Phytopathology. 9: 808- 811.

Missbah M. E. I., Aujjar N., Belabed A., Dessaux Y. and Filali-Maltouf A. 1996. Characterization of rhizobia isolated from carob (Ceratonia siliqua L.). J. App. Bacteriol. 80:165-173.

Murry M.A., Zhang D., Schneider M. And De Bruijn F. 1995. Use of repetitive sequences and the polymerase chain reaction (rep-PCR) to fingerprint the Frankia isolates. Symbiosis, 19: 223-240.

Nick G. and Lindstrom K. 1994. Use of repetitive sequences and the polymerase chain reaction to fingerprint the genomic DNA of Rhizobium galegae strains and to identify the DNA obtained by sonicating the liquid culture and root nodules. Syst. Appl. Microbiol. 17: 265-273.

Niemann S., Puehler A., Tichy H.Y., Simon R. and Selbitschka W. 1997. Evaluation of the resolving power of three different DNA fingerprinting methods to discriminate among isolates of a natural Rhizobium meliloti population. J. Appl. Microbiol. 82: 477-484.

O'Callaghan K. J., Davey M. R. and Cocking E. C. 1997. Xylem colonization of the legume Sesbania rostrata by Azorhizobium caulinodans. Proc. $R$. Soc. Lond. B. 264: 1821- 1826.

Ogutcu H. Adiguzel A. Gulluce M. Karadayi M. and Sahin F. 2009. Molecular characterization of Rhizobium strains isolated from wild chickpeas collected from high altitudes in Erzurum-Turkey. Rom. Biotechnol. Letter. 2: 4294-4299. 
Prabhat N.J., Garim G., Prameela J and Rajesh M. 2013. Association of rhizospheric/endophytic bacteria with plants: a potential gateway to sustainable agriculture. Greener J. Agri. Sci., 3: 73-84.

Rademaker J.L.W. and De Bruijn F.L. 1997. Characterization and identification microbes by rep-PCR genomic fingerprinting and computer assisted patterns analysis. In: Caetano-Anoliés G. Gresshoff PM (eds) DNA markers: Protocols Applications and Overviews. Willey, New York, pp 151-171.

Reva, O. N., Smirnov V.V., Pettersson B., and Priest F. G. 2002. Bacillus endophyticus sp. nov., isolated from the inner tissues of cotton plants (Gossypium sp.). Int. J. Syst. Microbiol. 52: 101107.

Reyes-Ramirez A. and Ibarra J. 2005. Fingerprinting of Bacillus thuringiensis type strains and isolates by using Bacillus cereus group-specific repetitive extragenic palindromic sequence-based PCR analysis. Appl. Environ. Microbiol. 71: 1346-1355.

Ryan R.P., Germaine K., Franks A., Ryan D.J. and Dowling D.N. 2008. Bacterial endophytes: recent developments and applications. FEMS Microbiol. Lett. 278: 1-9.

Schulz B. and Boyle C. 2006. What are endophytes? Microbial Root Endophytes (Sculz BJE, Boyle CJC and Sieber TN, eds). Springer-Verlag. Berlin, pp 113.

Shishido, M., Breuil C. and Chanway C. P. 1999. Endophytic colonization of spruce by plant growthpromoting rhizobia. FEMS Microbiol. Ecol. 29: 191196.

Singh R.K., Malik N. and Singh S. 2013. Impact of rhizobial inoculation and nitrogen utilization in plant growth promotion of maize (Zea mays L.). Bioscience, 5: 8-14.

Spigaglia P. and Mastrantonia P. 2003. Evaluation of repetitive element sequence-based PCR as a molecular typing method for Clostridium difficile. J. Clin. Microbiol. 4:2454-2457.

Stone, J. K. (1986). Foliar endophytes of Pseudotsugamenziesli (Mirb) Franco. Cytology and physiology of the host-endophyte relationship. DSc Thesis, Univ. of Oregon, Eugene, Canada.

Strobel G., Daisy B., Castillo U. And Harper J. 2004. Natural products from endophytic microorganisms. J. Nat. Prod. 67: 257-268.
Sturz A.V. and Matheson B.G. 1996. Populations of endophytic bacteria which influence hostresistance to Erwinia-induced bacteria soft rot in potato tubers. Plant Soil. 184: 265-271.

Tajima S., Yoshihara K., Bhromsin A. and Nomura M. 2000. Application of repetitive extragenic palindromic (REP)-PCR and enterobacterial repetitive intergenic consencus (ERIC)-PCR analysis to the identification and classification of Japan and Thai local isolates of Bradyrhizobium japonicum, Shinorhizobium meliloti and Rhizobium leguminisarum. Soil Sci. Plant Nutr., 46: 241-247.

Van Thi P. N and Cao Ngoc D. 2014. Isolation, characterization and phylogenetic analysis of endophytic bacteria in rice plant cultivated on soil of Phu Yen provence, Vietnam. Amer. J. Life Sci. 2(3): 117-127.

Versadovic J., Koeuth T. and Lupski J. R. 1991. Distribution of repetitive DNA sequences in eubacteria and application to fingerprinting of bacterial genomes. Nucl. Ac. Res. 19: 6823- 6831.

Verslovic J. T., Schneider M., de Bruijn F. J. and Lupski J. R. 1994. Genomic fringerprinting of bacteria using repetitive sequence-based polymerase chain reaction. Methods Mol. Cell. Biol. 5: 25- 40.

Vincent, J. M. 1970. A manual for the practical study of root nodule bacteria. IBP (Int. Biol. Programme) Handbook 15 Blackwell, Scientific Publcations. Ltd. Oxford.

Webster, G., Gough C., Vasse J., Batchelor C. A., O'Callaghan K. J., Kothari S. L., Davey M. R., Dénarié J. and Cocking E. C. 1997. Interaction of rhizobia with rice and wheat. Plant Soil. 194: 11522.

Winer N. 1980. The potential of the carob tree (Ceratonia siliqua). In Tree Crops J. 1: 15-26.

Yanni Y. G., R. Y. Rizk, V. Corich, A. Squartini, K. Ninke, S. Philip-Hollingsworth, G. Orgambide, F. De Buijn, R. Stoltzfus, D. Buckley, T. Schmidt, P. F. Mateos, J. K. Ladha, and F. B. Dazzo. 1997. Natural endophytic association between Rhizobium leguminosarum bv. Trifolii and rice roots and assessment of its potential to promote rice growth. Plant Soil. 194: 99- 114

Yousr Z., Nada B.B, Faysal B.J., Salah R. and Taoufik B. 2014. Effects of controlled mycorrihization on production of Jacaranda mimosifolia D. Don. Greener J. Agri. Sci., 4: 178-186. 